\title{
Regulation of Truckers For Hire in California
}

\author{
Boris H. Lakusta*
}

Noт so many years ago there were no highway motor carriers. Horsedrawn wagons and ox-drawn prairie schooners, sailing ships, steamships, river boats and railroads carried the freight of the mineteenth century. It was not until several years after 1900, when the gasoline engine had developed some reliability, that much thought was given to the motor carrier as a practicable or widespread means of freight transportation, and it was not until about 1915, with the impetus of the first World War, that there were noticeable indications of the impact which motor transportation was one day to engender in the freight carrying field.

It is, of course, common knowledge that even as the motor vehicle developed in efficiency and road projects began to be undertaken to accommodate it, the horse-drawn vehicle dwindled in importance as a mode of freight hauling for short distances. The transition was attended with little conflict, the same carrier often continuing to perform the service, merely substituting the more efficient gasoline engine in place of horses. Not so with the railroads which by the turn of the century had invested enormous capital and expanded to the furthest reaches of the land. When, during the first World War the imminence of truck competition was finally upon them, their first reaction was to combat motor carriers by rate cutting and by striving to have such carriers regulated in the same manner as themselves. It was only later that they took steps, and even then only to a very limited extent, to employ motor trucks as a substitute or auxiliary for rail service.

We know in retrospect that the rails have continued as a highly important means of freight transportation, and there is reason to believe that their importance will continue into the indefinite future, but we also know that prodigious strides have been made by motor carriers during the last thirty-five or forty years and that the transportation which they provide has come to play a major role in our economy, side by side with that of rails.

Califorma has been in the forefront among the states vitally affected by motor carriers. In the words of Senator Collier, California "has grown to economic maturity during the motor vehicle era. The industrial and agricultural pattern of the older eastern states had become stabilized before the automobile age. By contrast, Califorma has experienced its most rapid development during the same period in which the greatest expansion has occurred in highway transportation." 1 A recent report reveals that by 1938 ,

* Senior Counsel, California Public Utilities Commission. Member, San Francisco Bar. The opinions expressed in this article are those of the author and do not necessarily represent those of the Commission.

1 The Legislature Takes a Look at California Highway Needs, address by Senator Randolph Collier, published by Senate of State of California, p. 8 (1945). 
the earliest year for which statistics are presented, motor carriers for hire in California were receiving $65.9 \%$ of the total gross operating revenues reported for all classes of for-hire intrastate transportation in the State, stean railroads accounting for $27.8 \%$, electric railroads $1.6 \%$, water carriers $2.4 \%$ and express carriers $2.3 \% .^{2}$ The report shows that the percentage for motor carriers clinibed more or less steadily fom 1938 to 1951, reaching in the latter year $75.7 \%$, the figure for steam railroads correspondnigly shrinking to $19.3 \%$. The year by year statistics seem to justify the observation that "the trucking industry is receiving a consistently increasing proportion of the total for hire revenues derived from the transportation of property." 3 In 1951 truckers for hire received the remarkable gross revenue of $\$ 351,327,716$ for their intrastate services in California.

As might be expected with an industry that burgeoned so fast, the legal problems attendant upon its regulation in Califorma have been nuanifold. Legislation has come haphazardly, largely to satisfy the pressures of the inoment. Today there are no less than seven different categories of truckers in California, the dividing lines between them being in some instances both highly impracticable and most difficult to determine. It is perhaps accurate to say that the nuajority of truckers under present law cannot be certain of their status. Inequities arise from differing degrees of regulation which as between classes work illogical detriments or benefits. The so-called "wildcat trucker," indifferent to statutory requirements, has often fared better than the more law-abiding operator. Action of the California Public Utilities Commission in adopting various policies within the framework of the statutes has proved only a partial solution to the inherent weaknesses in the present law. Looked-for assistance from certain decisions of the California Supreme Court has not been forthcoming.

It will be the plan here to trace the nore important steps in the development of motor carrier regulation in the state. It is believed that a knowledge of such development forms a necessary background to full understanding of the problems prevailing today. The nature of those problems will be considered as the history progresses. For convenience the study is divided into periods according to certain major occurrences.

\section{The Period Prior to 1911}

The first action taken by Califorma to regulate its public utilities, aside from local regulation, was the act of April 3, 1876 which provided for three Commissioners of Transportation who were given very limited jurisdiction over the rates and service only of steain railroads. ${ }^{4}$ With the adoption of the new constitution three years later in 1879, provision was made in Article XII, Section 22, for a three-member Railroad Commission with power to fix rates and prescribe uniform systems of accounts for railroads "or other

2 Revenue and Equipment Statistics, Carriers of Property, prepared by Floyd McColl, Chief of Division of Permits and Fees, California Public Utilities Commission (April, 1952).

3 Ibid.

4 Cal. Stats. 1875-76, p. 783. 
transportation companies," and Article XII, Section 17 declared "all railroad, canal and other transportation" companies" to be "common carriers, and subject to legislative control." In implementing legislation the following year, transportation companies were defined to include railroads and certain steamship and steamboat operations. During the next twenty-nine years, between 1880 and 1909, there was no further legislation affecting the Railroad Commission. In 1909 an act was passed ${ }^{6}$ extending the definition of transportation companies to include "express companies" and "sleeping car companies" but making no specific references to truckers over the highways. At the next session of the legislature, in 1911, certain additional powers were given the commission over "railroads and other transportation companies."

\section{The Period from 1911 to 1925}

It was Governor Hiram Johnson, the vigorous advocate of nore extensive regulatory control for railroads and other utilities, who became the leading spirit in the novement which culminated in the submission by the legislature to the electors, and the latters' adoption on October 10, 1911, of the sweeping constitutional amendments which forn the basis of the powers vested today in the California Public Utilities Commission. ${ }^{8}$ Section 22 of Article XII was amended to create the five-member Railroad Commission. ${ }^{\circ}$ The existing language in that section to the effect that the commission shall have power to establish rates for the transportation of freight by railroads "or other transportation companies" was, with minor modification, retamed. The language in Section 17 of Article XII declaring "all railroad, canal, and other transportation companies" to be common carriers subject to legislative control was left unchanged. Section 23 was amended to declare a long list of organizations, including "every common carrier," to be public utilities subject to such regulation by the Railroad Commission as the legislature might enact.

In the same year, 1911, the legislation we know as the Public Utilities Act was passed to implement the new constitutional provisions. ${ }^{10}$ The only specific references in the new legislation to motor vehicle transportation over the highways occurred in Section 1(k), defining express corporations to include those engaged in the business of transporting freight for compensation "on the line of any common carrier or stage or auto stage line" and Section 33 dealing with through routes and joint rates for "common carriers and stage or auto stage lines."

It was not long after the passage of the Public Utilities Act that the rail-

\footnotetext{
5 Cal. Stats. 1880, p. 45.

0 Cal. Stats. 1909, p. 499.

TCal. Stats. 1911, p. 13.

8 CAL. Const. Arts. XI, XII (1911 Amendments).

$\checkmark$ On November 5, 1946, Art. XII, \$22 was amended and provided, among other things, that the Railroad Commission would be continued in existence as the Public Utilities Coun-

10 Cal. Stats. 1911, p. 14.
} mission. 
roads began to show concern over the increasing number of motor carriers for hire. On July 10, 1915 a group of railroads filed a case with the Railroad Commission to test the latter's jurisdiction over "motor bus lines, auto truck lines or auto stage lines engaged in the business of transporting freight for compensation for the general public over regular routes." The commission concluded that such motor carriers, even though common carriers at common law, were not "public utilities" and not "common carriers" as defined in the Public Utilities Act and therefore declined to take jurisdiction. ${ }^{11}$

In the mandate proceedings which followed, ${ }^{12}$ the California Supreme Court agreed that the Public Utilities Act did not confer jurisdiction, but it found that the operators in question, being common carriers and therefore public utilities under Article XII, Section 23, were "other transportation companies" within the meaning of Article XII, Section 22, even though the same phrase in the 1879 version of Section 22 had been construed somewhat narrowly; ${ }^{13}$ and it concluded, to the surprise of many, that Section 22 was self-executing, requiring of its own force that the commission exercise jurisdiction.

Thus for the first time motor carriers which were "common carriers" under the common law and under the California constitution, though not under the Public Utilities Act, were subjected to regulation by the state commission. Article XII, Section 22, gave authority to establish rates, examine books, hear and determine complaints, issue subpoenas, administer oaths, take testimony, punish for contempt, and prescribe a uniform systein of accounts. However, it was clear that detailed, supplementing legislation would be desirable. At the 1917 session the first comprehensive enactment known as the Auto Stage and Truck Transportation Act was passed. ${ }^{14}$ Using the same phrase as in the constitutional provision, the enactment applied to all "transportation companies" and provided regulation generally comparable to that in the Public Utilities Act for railroads, gas and electric compamies, telephone and telegraph companies and other utili-

11 Western Ass'n of Shortline Railroads v. Wichita Transportation Co., 8 C.R.C. 220 (1915). (1916).

Western Ass'n of Shortline Railroads v. Railroad Comm'n., 173 Cal. 802, 162 Pac. 391

13 Railroad Comm'rs v. Market Street Ry, 132 Cal. 677, 64 Pac. 1065 (1901). In that case it was held that "railroad and other transportation companies" in Art. XII, $\$ 22$ in the 1879 constitution did not include street railway companies carrying passengers for hire within the municipal limits. The court declared, arguendo: "Companies engaged in draying, running freight wagons, delivery-wagons, delivering parcels, teaming, or running elevators, are engaged in the business of 'transportation'; but it surely could not be contended that they are subject to the jurisdiction of the 'railroad commission.' "Id. at 684, 64 Pac. at 1068. In the Western Association case the court explanied away such obiter as referring solely to operations within the boundaries of a municipality.

Compare the recent proceedings involving the rates of airlines operating intrastate in which the commission's position that Art. XII, $\$ 22$ applied and was self-executing was sustained. California Central Airlines, 50 Cal. P.U.C. 563 (1951); United Air Lines, Decision No. 45709 (unreported) ; and Western Airlines, Decision No. 45710 (unreported) ; review denied sub. nom., United Air Limes v. California Pub. Ut. Comm'n., Sup. Ct., S. F. No. 18426 and Western Air Lines v. Public Ut. Comm'n, Sup. Ct., S.F. No. 18427; appeal dismissed, 342 U.S. 908 (1952). 14 Cal. Stats. 1917, p. 330. 
ties. A "transportation company" was defined as one engaged in the "transportation of persons or property as a common carrier for compensation over any public highway in this state between fixed termini or over a regular route and not operating exclusively within the limits of an incorporated city or town ...."15 Significantly the act was confined to operations "as a common carrier." Significantly too, it was confined, even as to common carriers, to operations "between fixed termini or over a regular route." The origin of that phrase, which has caused so much difficulty in later years, is not clear, but it is believed to have been responsive to the railroads' demands that trucking carriers operating in a manner similar to that of rails, be subjected to corresponding regulation.

In 1919 the definition section was nodified slightly but in a way which was to have troubling consequences. It was aniended to apply to those operating auto trucks or auto stages "used in the business of transportation of persons or property, or as a common carrier, for compensation, over any public highway in this state between fixed termini or over a regular route, and not operating within the limits of an incorporated city or town ...."18 The amending words appeared to have the effect of subjecting to state regulatory control all for-hire auto truck and auto stage operators between fixed termini or over regular routes, whether common carrier or not.

A number of cases reached the courts after the 1919 amendment, none of which raised the question whether the Railroad Commission's jurisdiction extended under the amendment to non-common carrier operations. ${ }^{17}$ Finally in 1924, a complaint was filed against one Frost, seeking a cease and desist order against the trucker for operations admittedly not common carriage. Frost engaged in the transportation of citrus fruits for a single corporation between Redlands and Los Angeles harbor pursuant to "private contract." The commission construed the Auto Stage and Truck Transportation Act, as amended in 1919, as applicable, and the carrier was ordered to cease operation in the absence of a certificate of public convenience and necessity. ${ }^{18}$ Upon review the California Supreme Court readily agreed with the commission's construction of the statute. ${ }^{19}$ It then undertook to consider the constitutional implications, both federal and state, and concluded the statute was not unconstitutional as applied to Frost's operation. Considering first the federal Constitution, it declared that the act, in its application to private carriers, ${ }^{20}$ "closely approximated" the result of

15 Cal. Stats. 1917 , c. $213, \S 1$ (c).

16 Emphasis added. Cal. Stats. 1919, c. $280, \S 2$.

17 Motor Transit Co. v. Railroad Comm'n., 189 Cal. 573, 209 Pac. 586 (1922); Coast Truck Line v. Railroad Comm'n., 191 Cal. 257, 215 Pac. 898 (1923) ; People v. Hadley, 66 Cal. App. 370, 226 Pac. 836 (1924); Truck Owners v. Superior Court, 194 Cal. 146, 228 Pac. 19 (1924); People v. Yahne, 195 Cal. 683, 235 Pac. 50 (1925) ; Franchise Motor Freight Ass'n v. Seavey, 196 Cal. 77, 235 Pac. 1000 (1925).

18 Happe v. Redlands Orange Growers Ass'n., 25 C.R.C. 297 (1924).

10 Frost v. Railroad Comm'n., 197 Cal. 230, 240 Pac. 26 (1925), reversed, 271 U.S. 583 (1926).

20 Since at least as early as the Frost case it has been the practice in California to designate non-common carriers for hire as "private carriers" or "contract carriers," as distinguished from "public carriers" or "common carriers." Those carrying their own property are designated "proprietary carriers." 
transforming them into public carriers by legislative fiat, in that the act imposed upon them the same burden as for common carriers, of rendering transportation service of the kind, character, and quality, and at the rates, prescribed by the commission. It denied that the act worked a mutation in fact from "a private carrier into a public carrier," a mutation which admittedly would constitute a deprivation of property without due process. The court argued that the act worked no compulsion to become a common carrier, allowing a private carrier the choice of accepting the regulation of the act or staying off the highways. Said the court, " . . the offer is conditional that the offeree shall return a consideration therefor [the privilege of using the public highways for business purposes] by dedicating his property to the quasi-public use of public transportation or, at least, by submitting himself to the conditions, regulations and restrictions specified in the act."21 Turning to the state constitution, the court concluded that the legislature had power under Article XII, Section 22, to confer jurisdiction upon the Railroad Commission over private carriers because such regulation is "cognate and germane" to the regulation of common carriers since "the private carrier is or at least may be in direct competition with the public carrier who is operating over the same route." 22

In the latter part of 1925 the California Supreme Court reiterated its views in Holmes v. Railroad Commission. ${ }^{23}$ However, the Frost case was shortly to come on for consideration by the United States Supreme Court, and in June, 1926, that Court rendered its decision. ${ }^{24}$ The high Court understood the California Supreme Court to have interpreted the Auto Stage and Truck Transportation Act to require a mutation from private to common carriage as a condition to the use of the state highways. The requirement of mutation standing alone, being admittedly unconstitutional under the fourteenth amendment, could not, said the Court, constitutionally be imposed as a condition to operation over the California highways. The reasoning of the Court was expressed thus: ${ }^{25}$

Having regard to form alone, the act here is an offer to the private carrier of a privilege, which the state may grant or deny, upon a condition, which the carrier is free to accept or reject. In reality, the carrier is given no choice, except a choice between the rock and the whirlpool-an option to forego a privilege which may be vital to his livelihood, or submit to a requirement which may constitute an intolerable burden.

It would be a palpable incongruity to strike down an act of state legislation which, by words of express divestment, seeks to strip the citizen of rights guaranteed by the federal Constitution, but to uphold an act by which the same result is accomplished under the guise of a surrender of a right in exchange for a valuable privilege which the state threatens otherwise to withhold. It is not necessary to challenge the proposition that, as a

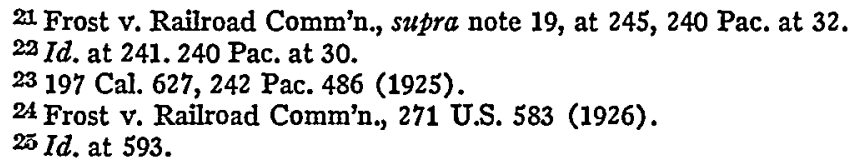


general rule, the state, having power to deny a privilege altogether, may grant it upon such conditions as it sees fit to impose. But the power of the state in that respect is not unlimited; and one of the limitations is that it may not impose conditions which require the relinquishment of constitutional rights.

With that prophetic insight which often enabled him to see further than his brethren, Justice Holmes (together with Justice Brandeis), in disagreeing with the majority, wrote that all the California court had been called upon to decide was whether a private carrier could be required to obtain a certificate as a condition to the use of the highways, and therefore any intimation of the California court that the Auto Stage and Truck Transportation Act imposed a condition that a private carrier transmute itself into a common carrier was gratuitous and not binding upon the high Court. Justice Holmes looked at the act for himself and declared that he saw nothing in it that would require private carriers to become common carriers, and that it was well within the legislative power, since automobiles were creating very great "difficulties of keeping the streets reasonably clear for travel and for traffic," ${ }^{26}$ to require all who operated automobiles for the transportation of persons or property over a regular route or between fixed termim on the public highways, for compensation, to obtain a certificate.

In retrospect the wisdom of Justice Holmes's reasoning seems clear. The question whether a particular carrier is common or private should not be confused with the question whether the state may constitutionally impose the same degree of regulation upon both. All the Auto Stage and Truck Transportation Act did was impose that same degree of regulation. It imposed upon private carriers the same requirements respecting certification, transfer, rates, accounting, service, reports, and the like, as were imposed for common carriers. Justice Holmes said that at least as to certification, which was the only matter before the court, there was no constitutional inhibition against the imposition of a requirement that all private carriers obtain a certificate as a condition to the use of the roads. It is not unlikely that the majority would have agreed with this conclusion, had they not gone off in another direction because feeling bound by what they understood to be the California court's construction of the statute, to the effect that the statute required mutation of status as a condition to operation. As will be noted subsequently, the confusion between the determination of status, on the one hand, and the degree of control which may properly be exercised once status is determined, on the other, continues even today to manifest itself as a lurking shadow stalking the efforts of the California Supreme Court in review proceedings.

One may well wonder what course the history of trucking regulation in California would have taken had the Califorma Supreme Court not used words susceptible of the interpretation given them by the majority of the Uinted States Supreme Court, that the Auto Stage and Truck Transporta-

26 Id. at 601 . 
tion Act required a private carrier to become a common carrier as a condition to the use of the highways. All highway carriers today, whether common or contract, serving between fixed termini or over a regular route and not wholly within the bounds of a city, might be operating under identical statutory regulation. As events turned out, contract carriers were entirely free for some ten years following the Frost decision. It was not until 1935 that legislation was enacted affecting them, but even then, control was largely limited in practice to the fixing of minimum rates, with virtually no control over entry into the contract carrier business or over facilities and service. That condition exists to this day.

During the same period that the Frost case was under consideration another circumstance occurred which further limited the scope of the Auto Stage and Truck Transportation Act, this time, however, in the common carrier rather than contract field. Its consequences were at least as serious. When in 1925 the Crittenden amendment of $1923,{ }^{27}$ amending the Auto Stage and Truck Transportation Act to exempt from regulation under that act "the movement of products or impleinents of husbandry and other farm necessities from farm to farm or from and to farm to and from loading poimt, warehouse or other initial point," was declared unconstitutional because creating an unwarranted classification, ${ }^{28}$ a flood of certificate applications poured in froin inotor carriers transporting farm and other products. The commission, not being sufficiently staffed to process them all immediately, stood to face a difficult admimstrative problem. However, the problein was avoided. In Ben Moore ${ }^{20}$ the conmmission, splitting 3 to 2, decided that the Auto Stage and Truck Transportation Act did not cover the kind of operation for which a certificate was sought. Ben Moore had requested a certificate for the transportation of general freight, including farm and factory products "between Sanger and any or all surrounding points, from farm to farm, farm to packing house, packing house to packing house and to railroads and miscellaneous other points not specifically named, within a radius of 75 miles from Sanger." 30 The service was to be "on call" and the proposed rates were on a mileage rather than a point to point basis. The commission, declaring that applicant had not alleged an intention to operate over any regular route or between any particular fixed termini, and that it planned to operate "on call," concluded that the proposed operation was not transportation "between fixed termini or over a regular route" within the meaning of Sections 1(c) and 1(e) of the Auto Stage and Truck Transportation Act. ${ }^{31}$ This conclusion was reached despite the fact that

27 Cal. Stats. 1923, c. 310.

28 Franchise Motor Freight Ass'n v. Seavey, supra note 17.

2027 C.R.C. 388 (1925), writ denied sub. nom., Harm v. Railroad Comm'n., Sup. Ct., S.F. No. 11972 (March 1, 1926).

$30 \mathrm{Id}$. at 389 .

31 Cal. Stats. 1917 , c. 213, as amended by Cal. Stats. 1919, c. 280. Section 1(c) as amended in 1919, defining "transportation companies," is quoted in the text, supra at note 16. Section 1(e) provided: "The words 'between fixed termini or over a regular route,' when used in this act, mean the termini or route between or over which any transportation company usually or ordinarily operates any automobile, jitney bus, auto truck, stage or auto stage, even though 
the operation in question did not contemplate any restriction on frequency of service between the numerous pairs of termini involved or over any of the numerous routes to be traversed.

In defense of the Ben Moore decision it must be conceded that the words "between fixed termim or over a regular route" were probably fashioned chiefly to cover operations between established commumities over main highways, for those were the operations which the railroads most feared. However, since all termini are geographically "fixed" and all routes are geographically "regular," it seems the words, to have any meaning at all, niust have had reference to frequency of service as making termim" "fixed" or routes "regular." This appears especially because the definition of the phrase "between fixed termini or over a regular route" speaks of "the termini or route between or over which any transportation company usually or ordinarily operates" as being the termini or routes intended to be covered. ${ }^{\mathbf{2}}$

The unfortunate effect of the Ben Moore decision must have been little foreseen. It meant that for the next ten years all common carrier operations which undertook to serve anywhere within a defined area or which radiated out to numerous termini froni a focal point tended to escape regulation, even where some frequency of service between given pairs of termini or over given routes prevailed. The effect was particularly unfortunate because such operations were precisely the kind which were bound to flourish in the state with its large cities widely separated, each tending to be an independent hub for much of the activity in the surrounding area. Even im 1935, when legislation was finally enacted to cover "radial highway common carriers," regulation was narrowly limited, covering primarily maximum-minimum rate control, with virtually no control over entry into the field or over facilities and service. Indeed, as will be seen, such operations were placed in the same act with contract carriers and subjected to the same narrow regulation. That condition prevails to this day.

\section{The Period from 1925 to 1935}

In the ten years between 1925 and 1935 the trucking industry expanded by leaps and bounds. While regulation was provided for common carrier operations between fixed termini or over regular routes, there was a broad field outside, wholly excluded froni regulation. The Frost case had decided that the existing statute could not constitutionally be applied to contract carriage, or as it is synonymously designated under California practice, private carriage. The Ben Moore case had made it clear that the commission would not entertaim applications for certificates for operations which were area-wide or which radiated out, the question of frequency in such

there may be departures from said termini or route, whether such departures be periodic or irregular. Whether or not any automobile, jitney bus, auto truck, stage or auto stage is operated by a transportation company 'between fixed termini or over a regular route' within the meaning of this act shall be a question of fact and the finding of the railroad commission thereon shall be final and shall not be subject to review."

82 Emphasis added. See quotation of $\S 1(\mathrm{e})$ in note 31 , supra. 
instances being ignored. As could be anticipated the trucking industry took full advantage of the absence of regulation in the broad field indicated.

If a carrier remained private, it could charge what it wished and operate as it saw fit. Furthermore its claim of private status was not easily overturned. Following the strict doctrine expressed in earlier water cases ${ }^{33}$ the California Supreme Court was wont to caution, in the words of Allen $v$. Railroad Commission: ${ }^{34}$ "to hold that property has been dedicated to a public use is 'not a trivial thing' ... and such dedication is never presumed 'without evidence of unequivocal intention.' " Of the six cases in which the supreme court rendered opinions during the period 1925 to 1935 , involving the determination of a trucker's status, common carriage was determined to have been correctly found in three instances. ${ }^{35}$ In the other three the court ruled that the carrier was private or contract. ${ }^{36}$ This is not to say that there were not a good number of proceedings before the Railroad Commission in which a claimed private or contract operation was found in fact to constitute common carriage and in which no court review was sought, or if sought, was denied. ${ }^{37}$

If a carrier's operation, even though admittedly common, could be said to be area-wide or radiate from a focal point, it usually escaped regulation as completely as the contract carrier's. In this respect, however, a curious anomaly developed. While in application proceedings the commission ignored the inatter of frequency and found a certificate urmecessary if the applicant contenplated a service area-wide or radiating from a focal point, ${ }^{38}$ in conplaint proceedings the commission was not loath to consider frequency and was willing to declare that the part of the operation which showed frequency of service was "between fixed termini or over a regular route" and therefore in need of a certificate under the Auto Stage and Truck Transportation Act. In the two decisions reaching the supreme court such action was approved. ${ }^{39}$

\footnotetext{
33 E.g., Allen v. Railroad Comm'n., 179 Cal. 68, 175 Pac. 466 (1918) ; Klatt v. Railroad Comm'n., 192 Cal. 689, 221 Pac. 926 (1923).

34 Supra note 33, at 85, 175 Pac. at 473.

35 Haynes v. MacFarlane, 207 Cal. 529, 279 Pac. 436 (1929) (use of contracts found under circumstances to constitute studied attempt to evade common carrier status); George v. Railroad Comm'n., 219 Cal. 451, 27 P.2d 375 (1933) (while carrier had contracts it had practically all the tonnage it could conveniently handle); Landis v. Railroad Comm'n., 220 Cal, 470, 31 P.2d 345 (1934) (as to one carricr involved, there were contracts but accompanied by a holding out to all within a certain class up to the limit of available equipment).

30 People v. Duntley, 217 Cal. 150, 17 P.2d 715 (1932); People v. Lang Transportation Co., 217 Cal. 166, 17 P.2d 721 (1932); Landis v. Railroad Comm'n., suspra note 35 (as to one of carriers involved). The sane conclusion was reached by the district court of appeal in Webb v. Boyle, 125 Cal. App. 326, 13 P.2d 785 (1932).

${ }^{37}$ Rice Transp. Co. v. Independent Co., 36 C.R.C. 840 (1931); Regulated Carriers v. Cohen, 38 C.R.C. 923 (1933); cert. denied sub nom., Cohen v. Railroad Comm'n., Sup. Ct., S.F. No. 14936 (July 6, 1933); Motor F. T. Co. v. Taher, 35 C.R.C. 757 (1931) ; Petaluma Ry. v. Baylinson, 35 C.R.C. 793 (1931); El Dorado M. T. Co. v. Ellis, 35 C.R.C. 588 (1930); Rasmussen Co., 34 C.R.C. 497 (1930); Petaluma Ry. v. Leal, 33 C.R.C. 63 (1929); Thornewill v. Gregory, 33 C.R.C. 455 (1929), 31 C.R.C. 843 (1928); Tucker v. Payne, 32 C.R.C. 200 (1928); Hodge v. Garver, 32 C.R.C. 412 (1928).

38 E.g., McConnel, 31 C.R.C. 628 (1928); Phoenix, 32 C.R.C. 169 (1928).

39 George v. Railroad Comm'n., 219 Cal. 451, 47 P.2d 375 (1933); Landis v. Railroad Comm'n., supra note 35 . The court in each instance took note of the fact, seemingly with ap-
} 
Inevitably the total absence of administrative control over a broad segment of the trucking industry between 1925 and 1935 tended to destroy the efficacy of regulation over, and to impose inequitable discrimination against, those carriers which did fall within the Auto Stage and Truck Transportation Act. Not only did truckers seek wherever possible to avoid regulation, either through a claim of being a contract or a non-fixed termini operator or through some device, ${ }^{40}$ but the very presence of a segment of the industry having no obligation to seek permission for entry into the field, no obligation to abide by any rate pattern and no obligation to maintain particular facilities or give particular service, rendered largely nugatory the regulation of the fixed-termini, regular route common carriers. This was particularly evident in the matter of rates, where cutthroat competition could not be successfully combatted. That rate control over only one of two competitors inust be futile was forcefully demonstrated in Lang v. Railroad Commission, ${ }^{41}$ in which the Supreme Court had before it the question of whether the commission could lawfully permit rail rates to go into effect which were admittedly designed to undercut the going rates charged by contract motor carriers for transporting petroleum and gasoline, the hope of the rails being to regain solne of the business they had once enjoyed as a monopoly. The problem would have been the same had certificated truckers subject to rate control been involved in place of the railroads. The court recognized the uselessness of rate regulation under such circumstances in the following words: ${ }^{42}$

To permit unrestrained and unregulated competition to be carried on between the rail carriers on the one hand and the tank truck carriers on the other will be disastrous to both parties.... On the other hand, to fix ... the rail rates, without regulating the rates to be charged by the truck carriers, and it is admitted that the commission has no authority over the rates to be charged by the truck [contract] carriers, would permit the latter to cut under the rail rates fixed by the commission, with the result that practically all of this business would leave the rail carriers and go to the truck carriers .... Until truck carriers are brought within the jurisdiction of the commission and the latter is given power to fix rates to be charged by them, we see no way that the Commission can stabilize this business between them and the rail carriers.

Finally, in December 1931, the Commission on its own motion instituted an investigation to inquire into the "very apparent unsettled state" 43 of freight transportation conditions, to take "positive regulatory action, even

proval, that the commission's determination of status as falling within the Auto Stage and Truck Transportation Act had excluded that part of the carrier's operation where service between pairs of termini was not frequent.

$40 \mathrm{See}$, for example, the devices employed in Motor Freight Co. v. Burke, 37 C.R.C. 59 (1932), cert. denied sub. nom., Business Men's Mutual Exch. v. Railroad Comm'n., Super. Ct., L. A. County Civil No. 13558 (May 12, 1932); Coast Truck Line v. California Merchants Ass'n, 37 C.R.C. 434 (1932).

41 Cal. 2d 550, 42 P.2d 639 (1935).

42 Id. at 564, 42 P.2d at 645 .

43 Transportation Investigation, 38 C.R.C. 81, 84 (1932). 
though it be of a most drastic character, that is necessary and possible under the existing law, or to make definite recommendations for legislative action, or both, as may be warranted in the public interest." 44 Extensive hearings followed which resulted in an opinion issued October $10,1932,{ }^{45}$ most of the observations in which are as pertinent twenty years later as they were when written.

The opimon ascribed the existing "transportation chaos" primarily to the anomalous circunistance of having essentially the same transportation service performed by carriers, one class of which was under strict regulation both as to rates and service and, therefore, unable to bid freely in the open market, and the other class, wholly free to do as it chose, both in rates and service, and devoid of all obligation. The evidence showed that an enormous volume of the business of the unregulated truckers was being conducted at less than the cost of service, affecting the prosperity of regulated carriers, curtailing the ability of the latter to serve the public and at the same time not promoting the prosperity of the unregulated truckers themselves-as indicated by the continued change in truck ownership and the lack of contmuity in operation. The introduction into a system of known transportation charges and practices, of a system of unknown transportation charges and practices was described as producing demoralizing results.

The opinion reached a general conclusion which has never been given legislative fulfillment but the wisdom of which seems proven with each passing year: ${ }^{46}$ "The public interest demands that regulation be extended alike over all or that it be withdrawn from all and the law of the jungle be given full and equal play." The commission declined to state which of these alternatives its considered preferable, saying that was a matter for legislative policy, but declared that if regulation was to continue, two specific things should be done: (1) eliminate the illogical distinction between those common carriers which operate between fixed points or over regular routes and those which do not, and make both of them subject to certification, rate, and service regulations; (2) require that contract carriers obtain certificates of public convenience and necessity upon the theory that "the use of the public higlwway by a transportation company for hire, even by private contract, at once clothes the business with a public interest," and that such use is a privilege whicl may be granted upon condition. ${ }^{4 r}$ Specifically the commission recommended that certificates be issued to contract carriers "upon a showing (1) of convenience and necessity, (2) financial responsibility, (3) an

44 Transportation Investigation, 38 C.R.C. 81,85 (1932).

45 Transportation Investigation, supra note 43. Much credit was due Warren $\mathrm{K}$. Brown, now the Commission's Director of Transportation, for the comprehensive character of the investigation and the thorough consideration given all phases of the problem.

46 Id. at 93.

4r Id. at 96 . The Commission's theory proved to be valid. Shortly afterwards, the United States Supreme Court in Stephenson v. Binford, 287 U.S. 251 (1932), upheld the validity of a Texas statute requiring permits for contract operations, such permits to be issuable only after hearing and a showing that the operations would not "impair the efficient public service of any authorized common carrier ...." The statute was upheld as a legitimate exercise of state pohice power over the use of highways. 
enumeration of the contract or contracts upon which the operation is based, and (4) a showing that the contract rates are not less than reasonable rates." ${ }^{48}$ The commission recommended, as a more drastic measure, that if contract carriers not be required to obtain certificates, they be prohibited from operatimg on the public highways altogether. ${ }^{49}$

In 1933 bills were offered in the legislature which incorporated im substantial respects the commission's recommendations..$^{50}$ Largely because of opposition from trucking interests, the bills were defeated.

Fimally in 1935 legislation was adopted which, with certain modifications, especially as affecting petroleum and household goods carriers, remains the effective law today.

\section{The Period from 1935 to 1946}

While the 1935 legislation was hailed with enthusiasm in some quarters, it fell far short of the goals the commission had recommended in 1932. The Auto Stage and Truck Transportation Act was repealed, but the unfortunate distinction between common carriers which operate between fixed termim or over a regular route, and those which do not, was perpetuated.

The fixed termini or regular route common carriers were placed in the Public Utilities Act, so to require certification, adherence to precise rates, obedience to service orders, and subjection in general to the provisions of that Act. ${ }^{51}$ Such treatment amounted in a sense merely to a transposition of the provisions of the Auto Stage and Truck Transportation Act, but it gave somewhat more complete control because of the comprehensiveness of the provisions of the Public Utilities Act. The truckers in this category were designated "highway common carriers."

The second category, defined in an awkward negative as those common carriers not covered by the first category and designated "radial highway common carriers" were placed in a new act called the Highway Carriers' Act. ${ }^{2}$ Strangely, contract carriers were also placed in this act. Again using the awkward negative definition technique, highway contract carriers were defined to be whatever were not common carriers, that is, whatever were not highway common carriers under the Public Utilities Act and whatever were not radial highway common carriers under the Highway Carriers' Act.

The new centaur-like Highway Carriers' Act, applying alike to that illconceived fragment of common carriage, called "radial" in a statute for the

48 Transportation Investigation, supra note 43 at 96 . An exception to such certificate requirement was recommended for contract carriers operating within a radius of thirty miles beyond the corporate limits of any city or village or shipping point, provided the operation not be between cities, villages or shipping points. Id. at 97 .

$49 I d$. at 98 .

50 Senate B. No. 1203, Assembly B. No. 406, Calif. Legislature, 1933 Reg. Sess.

51 Cal. Stats. 1935, c. 664, added $\$ \$ 23 / 4$ and 503/4 to the Public Utilities Act (Stats. 1915, c. 91). The corresponding sections for $\S 23 / 4$ are now found in CAL. PUB. UT. CoDe $\$ \S 211,213$, 214, 215, 1072. The corresponding sections for $\$ 503 / 4$ are now found in CAL. PUB. UT. CodE $\S \S 1061-1071$.

52 Cal. Stats. 1935, c. 223, §§ 1(1), 1(i), now contained in CaL. PuB. UT. Code $\S \S 3516$, 3517 (see note 51, supra). 
first time, and to the non-common carrier called "contract", provided initially for the possession of a "permit" as a condition to doing business. Unlike a certificate, however, the permit requirement was a hollow thing. Issuance was not predicated upon "convenience and necessity" or upon some other less crystallized test such as "public interest," or even upon a showing of ability to perform or financial responsibility. Issuance was predicated only upon (1) the filing of an application setting forth full information concerning the financial condition and physical properties of applicant "and such other information necessary to the enforcement of this act, as the Railroad Commission may, by order require"; $; 3$ (2) the procuring and filing of certain mimimum public liability and property damage insurance; ${ }^{54}$ and (3) the paying of a fee of $\$ 3.55$ If an applicant complied with these requisites, "a permit must be issued by the commission." 60 While this language has never had judicial consideration, the commission has interpreted it in practice as imposing simply a ninisterial function, except in certain cases where a permit has previously been cancelled for violation or noncoinpliance with the statute or commission orders.

In addition to the permit requirement, the Highway Carriers' Act authorized the commission to "establish or approve just, reasonable, and nondiscriminatory maximum or minimum or maximum and minimum rates," and provided that in any event "such rates shall not exceed the current rates of common carriers for the transportation of the same kind of property between the same points." 57 While the Highway Carriers' Act did not, like the Public Utilities Act covering highway common carriers, provide for the filing and observance of precise rates together with a prohibition against increasing them without Commission authority, it did tie the rates of all carriers, railroad, highway common, radial highway common and highway contract, together to the extent of placing a ininimum, whenever the commission took advantage of the authority given it to prescribe minima, beneath which no carrier could go. ${ }^{58}$ The system spelled the end of the ruinous rate wars between the railroads and certificated carriers, on the one hand, and the previously unregulated carriers, on the other.

The Highway Carriers' Act contained no provision comparable to Sections 13 and 35 of the Public Utilities Act, ${ }^{\text {t9 }}$ giving the commission authority to prescribe "adequate, efficient, just and reasonable" service and facilities, so to promote the safety, health, comfort and convenience of patrons, employees and the public. There was the requirement, however, that certain public liability and property damage insurance be maintained.

The Highway Carriers' Act contained a prohibition against operation

53 Cal. Stats. 1935, c. $233, \S 3$.

$54 I d ., \$ \S 5,6,7$.

55 Id., \& 9 .

58 Id., $\$ 3$.

57 Id., $§ 10$.

5s The statute authorized the Commission to permit less than minimum rates in special cases. Cal. Stats. 1935, c.223, $\$ 11$.

58 Cal. Stats. 1915, c.91, now CaI. Pob. UT. Code $§ \$ 451,761$. 
both as a "common carrier and as a highway contract carrier of the same commodities between the same points."60

Finally the Highway Carriers' Act contained provisions for cancellation of the radial or contract permit in the event of violation of any provision of the act or of commission orders under it, and declared such violations to constitute a misdemeanor, and to subject the violator not only to criminal prosecution but also to penalty action.

In the regulatory scheine developed by the 1935 legislation, all operations exclusively within the limits of a single incorporated city or town were excluded both from the Public Utilities Act ${ }^{61}$ and from the new Highway Carriers' Act. ${ }^{62}$ Separate legislation entitled the City Carriers' Act was passed to cover operations thus excluded. ${ }^{63}$ It was patterned closely after the Highway Carriers' Act and contained in general the same permit, minimummaximuin rate, and violation provisions. It is important to note, however, that in this one narrow field, operations within a city, uniformity of regulation between all classes of carriers was, indeed, achieved. The new act made no distinction whatever between common, radial common and contract carriers. All were described simply as "carriers" and as such were made subject to all the provisions of the act. It is siguificant that little administrative difficulty has been encountered under the City Carriers' Act and that little dissatisfaction has been voiced by anyone, carrier or shipper. It is undoubtedly true that the restricted field enconipassed by the City Carriers' Act is artificial in this day when the political boundaries of cities bear little relation to the economic activity of the commmity, and that there appear to be no cogent reasons why intracity carriers should be put in a separate class and given different treatınent fronu carriers serving broader territories, but the City Carriers' Act does suggest a course toward solving regulatory problems on a broader plain.

It was not long after the passage of the 1935 enactments that the power of the legislature to confer regulatory control of the kind provided in the Highway Carriers' Act and the City Carriers' Act over contract or private carriers was challenged. In Morel v. Railroad Commission ${ }^{\text {th }}$ the validity of the City Carriers' Act, and especially the permit requirement thereof, as applied to a private city carrier, was upheld, first as being authorized under Article XII, Sections 22 and 23 of the State Constitution because the regulation of the business of private carriers, whether or not operating between fixed termimi or over regular routes, is "coguate and germane" to the regulation of the business of a common carrier engaged in like transportation, and second, as being not violative of the guaranties of the Fourteenth Amendment inasmuch as the state has power incident to the preservation of highways to impose upon private carriers any conditions which "in any degree,

60 Cal. Stats, 1935, c.223, \$4.

61 Cal. Stats. 1935, c.664, $\$ 23 / 4$.

62 Cal. Stats, 1935, c.223, § 1 (f).

63 Cal. Stats. 1935, c.312.

of 11 Cal. 2d 488, 81 P.2d 144 (1938). 
or under any reasonably conceivable circumstances" bear an actual relation to such preservation. It was pointed out that, unlike the Auto Stage and Truck Transportation Act which had been understood by the United States Supreme Court in the Frost case ${ }^{66}$ to require a transmutation to common carriage as a condition to operation, the City Carriers' Act did no more than impose upon a private carrier conditions less stringent than those upheld by the United States Supreme Court in Stephenson v. Binford. ${ }^{87}$ It was particularly noted that one of the express purposes of the City Carriers' Act, as set forth in its preamble, was the preservation of the highways and that the legislature had declared it necessary to that end to regulate the use of the highways by those transporting property thereon for commercial purposes.

It was clearly implied in the Morel case ${ }^{68}$ that its holding would apply a fortiori under the Highway Carriers' Act. A year later the question was squarely decided in Entremont $v$. Whitsell, ${ }^{60}$ which involved the validity of a commission minimum rate order under the Highway Carriers' Act as applied to a private carrier. The court merely referred to the Morel decision as controlling on that point.

In the years between 1935 and the beginning of World War II, the problem of inequality im regulation which had been the subject of so much concern between 1925 and 1935 was largely taken care of, so far as rates were concerned, by the minimum-maximum rate provisions in the Highway Carriers' Act, ${ }^{70}$ but other inequalities persisted, especially in the matter of prerequisites for the commencing of operations. Certainly the requirement of a permit which was issuable as a matter of course upon the filing of an application, paying a small fee and showing adequate insurance, was an insignificant burden by contrast to the requirement of proving convenience and necessity. Increasing numbers of new operators were coming into the field, purchasing at least one and often all three of the available permits, radial, contract, and city, for a total of $\$ 9$, and upon the strength of such permits undertaking a service hardly distinguishable in practice from that being performed under difficult-to-obtain certificates of public convenience and necessity. The elusive distinction between the two types of common carriage, based upon the "fixed" or nonfixed character of termini or the "regular" or nonregular character of routes, and the almost equally difficult-toapply distinction between common and private carriage, only promoted the tendency to follow the easy course of obtaining permits and ignoring certificates. The rather hidebound policy of the commission, rooted in habits of thinking more appropriate to the rail, electric, gas, telephone or water fields

65 II Cal. 2d 488, 499, 81 P.2d 144, 149, quoting Stephenson v. Binford, supra note 47, at 272.

60 Frost v. Railroad Comm'n., supra note 24.

67 Supra note 47.

68 Morel v. Railroad Comm'n., supra note 64, at 496, 81 P.2d at 148.

6913 Cal. 2d 290, 89 P.2d 392 (1939).

To Immediately after the 1935 legislation the Commission embarked upon a statewide minimum rate program and, by successive steps, minimun rates were established for practically all commodities. See Carriers of Property, 48 Cal. P.U.C. 587, 593 (1949). The Commission has never embarked upon a maximum rate program. 
where monopoly is desirable, to grant certificates only upon a showing that existing carriers were not performing a needed service, only aggravated the situation. Finally, for men occupied in so practical and down-to-earth a business as trucking, there was an innate distaste for esoteric inquiries into the legal niceties of whether what they were doing should be classified as one kind of carriage or another. Obtaining permits rather than certificates appealed to them as the simplest, most practical method of giving regulation its due without becoming enmeshed in long hearings and tight restrictions.

The effect of the great influx of "pernnitted" truckers performing substantially the same service as certificated carriers and in any case seriously competing with the latter, was a matter of grave concern to the commission. Except for the rate problem, now largely cured, it was a recurrence or rather a continuation of the problems which had disturbed the commission in 1932. The whole concept of certification as a justified exercise of the power of the state in connection with businesses affected with a public interest, was being undermined by the inroads of a group subject only to the token requirement of a permit and able more and more to seize the very business upon which the life of the certificated carriers depended. To remedy the situation, bills were introduced in the legislature both in $1939^{\mathrm{TI}}$ and $1941,^{72}$ designed to amend the Highway Carriers' Act to provide for a certificate of public convenience and necessity (in place of the permit requiring no showing) as a prerequisite to doing business as a radial highway common carrier, and for a permit based upon a showing of public interest (in place of the permit requiring no showing) as a prerequisite to doing business as a highway contract carrier. The efforts to obtain passage of the bills proved abortive in each instance.

By 1941 many of the permitted carriers had grown to enormous size, carrying large tonnages daily between various termini over the state, and could no longer by any stretch of the imagination clain to be radial or contract carriers. In that year a number of them filed applications for certificates. $^{73}$ Before the hearings had progressed far, Pearl Harbor had been bombed. Hearings were discontinued for the duration of the war. The Federal Government, through the Office of Defense Transportation and other agencies, undertook to utilize all available trucking for the vast movement of war supplies. Local regulation, whenever inconsistent, gave way to federal requirements, and local problems were for the time being put to one side.

\section{The Postwar Years}

With the return of peace, the old problems loomed once again, but now in greatly exaggerated form. Truckers which had mushroomed into large organizations during or just preceding the war were to be found in inany

71 Senate B. No. 624, Calif. Legislature, 1939 Reg. Sess.

72 Senate B. No. 567, Calif. Legislature, 1941 Reg. Sess.

73 E.g., Savage Transportation Co., Application No. 23877; Associated Freight Iines, Application No. 24057; Willig Truck Transportation Co., Application No. 24107; Hart Transportation Co., Application No. 24124. These were all subjects for the decision in 48 Cal. P.U.C. 712 (1949). 
quarters, operating without benefit of certificate but seemingly performing service for the general public regularly between the larger communities of the state. A number had filed applications for certificates to do what they were in fact doing ${ }^{74}$ but a great many more were resisting any charge of unauthorized operation. The total number of permitted carriers, that is, carriers possessing one or more permits, had risen from 7984 as of June 30, 1938 , to 13,426 as of June 30,1946, and to 14,787 as of June 30, 1947.

The commission had the immediate practical problem of determining what disposition to make of applications for certificates made by carriers which sought certificate sanction for the very kind of operation they had been engaging in since some indefimite period in the past. Presumably the past and current operations were unlawful, though never officially so declared, and the argument was made that that circumstance should, as it had in prewar years, be considered per se ground for denial of a certificate. Against such position was the argument that the carriers in question were in fact serving large numbers of shippers, and in most instances with at least as much efficiency as the existing certificated carriers. Finally the unequal system whereby one type of common carrier authority required proof of convenience and necessity whereas another required no proof whatever, cast $m$ doubt the whole purpose of certification and the content to be given that phrase of art "convenience and necessity."

The commission pursued a number of courses in an effort to resolve the difficulties pressing upon it, but only after it had first undertaken a new investigation, instituted in the spring of $1946,{ }^{75}$ to inquire into the entire transportation problen. After extensive hearings with all interests represented, carrier and shipper, an opinion was rendered April 13, 1948, ${ }^{\pi}$ followed by a supplemental opinion a year later on March 22, 1949. ${ }^{77}$ Again stress was laid upon the incongruity of disparate regulations for common carriers classified according to the abstruse test of whether their operations were or were not "between fixed termini or over a regular route." Attention was given also to the need for more effective control over private carriers. Together these opinions present an excellent and comprehensive exposition of the regulatory problems with which the commission was faced.

The supplemental opinion recommended remedial legislation, but in addition it announced certain policies for the future which it felt would tend to ameliorate the "recognized chaotic transportation condition" even in the absence of statutory changes.

As to legislation, the commission appended to its supplemental opimon the exact amendments it proposed. Radial carriers were to be designated "irregular route highway common carriers" and placed in the Public Utilities Act so to be subjected to the same regulation as highway common car-

74 E.g., those carriers which were the subjects for decision in Savage Transportation Co., 48 CaI. P.U.C. 712 (1949).

75 Case No. 4823, filed March 26, 1946.

76 Carriers of Property, 48 Cal. P.U.C. 62.

T7 Supra note 70. 
riers. There were grandfather provisions allowing existing radial carriers the right to become certificated for the operations they were in fact performing merely upon the filing of an appropriate application "without further showing of public convemience and necessity.". Contract carriers were to continue in the Highway Carriers' Act, but permits henceforth were to be issued only if ability, experience, financial responsibility and public interest could be established. There were grandfather provisions to enable existing contract carriers to obtain the new kind of permit without a showing of "public interest." The commission was to be given authority to attach to permits "such terms and conditions as, in its judgment, the public interest requires." The fee for applications was to be increased from $\$ 3.00$ to $\$ 25.00$. Permits henceforth were to be transferrable, but only upon commission authorization. Contract carriers henceforth were to be required, as a condition to operation, to file with the commission evidence of written, bilateral contracts with the shippers served. Recommended legislation was also set forth for city carriers, amending the City Carriers' Act to require, as in the case of contract carriers, that permits be issued only if ability, experience, financial responsibility and public interest were established.

In the matter of policy, the commission made important pronouncements which it subsequently put into effect. It declared that the commission would be liberal in granting certificates, invited all contract and radial carriers having reason to believe their operations were in fact highway common carriage to make certificate application, and announced a strict enforcement program for both status and rate matters in the future.

The policy of liberality in the granting of certificates was dictated by a number of factors all pointing toward the commission's belief that a "sounder transportation system," with better service at lower cost, could be achieved by fuller administrative control. This represented a solnewhat more affirmative position than that in 1932 when the commission had emphasized equality rather than fullness of control. It was noted that permitted truck operators had become the dominant carriers in Califormia, not only in numbers but in tonnage hauled, ${ }^{78}$ that the turnover among them was high, causing a continuing dilution of available traffic and tending to push rates upward, that their legal status was difficult to determine, that a large percentage were probably highway common carriers in fact, that in any case limited control over so large a segment of the industry was less desirable than the more rigid control provided in the Public Utilities Act. As further justification for liberality, it was noted that almost no new certificates had been granted since prior to World War II, despite tremendous population increases and industry growth. To counter the position of existing certificated carriers that they should be afforded some protection against newcomers seeking certification, the commission declared that transportation does not flourish best as a regulated monopoly and that the aim of admin-

78 The opinion stated that there were 14,361 permitted carriers on June 30,1948 , as against approximately 200 certificated carriers, that between the San Francisco and Los Angeles metropolitan areas about $82.5 \%$ of the tonnage was being moved by permitted carriers. $I d$. at 594 . 
istrative regulation in the trucking field should rather be regulated competition. The commission might have added that so long as radial and contract permits could be had merely by paying a fee, there would always be a strong element of competition for the existing certificated carriers to meet, no matter how illiberal or sparing the policy in issuing certificates or how vigorous the enforcement of certificate requirements.

Immediately after the commission had issued its supplemental opinion, ${ }^{79}$ steps were taken to give effect to the statements contained in it. The new policy was given application simultaneously with efforts to secure proposed remedial legislation for it was felt that, even should legislation fail, the new policy would go at least a part of the way in curing existing inadequacies.

The first action was to grant certificates in the so-called Savage cases, some of which had been pending as far back as $1941 .^{80}$ In these consolidated proceedings certificates were given to some fourteen large operators to transport generally between the San Francisco and Los Angeles areas, also in certain instances between certain other points in the state. The decision was significant not only because it broke dramatically from the long-standing predisposition to hold that convenience and necessity could be established only by showing inadequacy of existing highway common carrier service, but because it determined that, in the light of economic circumstances, the advent of war, and the difficulty of determining status, prior unauthorized operation would not, even if proved, have evidentiary weight against the issuance of certificates.

The effect of the decision was virtually to hold that, if an applicant could demonstrate an efficient existing service to a substantial number of satisfied shippers, a certificate would be issued for the termini and the commodities in question. The commission went so far as to declare: "Public convenience and necessity require that those carriers hauling the bulk of the tonnage should have public utility obligations." 81 The competitive effect of a new certificate upon existing highway common carriers already in the field was deemed of no consequence "to the extent that it does not impair the economic stability of the transportation industry." 82

The content given the term "public convenience and necessity" in the Savage cases has to date been applied in a considerable number of proceedings where carriers have taken advantage of the invitation to seek certification. ${ }^{83}$ There are currently some 400 certificated carriers in the state, as contrasted with half that number in 1948. How long the policy

79 The supplemental opinion, supra note 70, is familiarly known as the Commission's "Policy Decision."

80 Savage Transportation Co., supra note 74.

81 Id. at 719.

82 Id. at 720 .

83 E.g., M. L. Morris, 48 Cal. P.U.C. 764 (1949); Peninsula Motor Express, 49 Cal. P.U.C. 807 (1950); Merchants Express Corp., 50 Cal. P.U.C. 392 (1951) ; E. Guy Warren, 50 Cal. P.U.C. 476 (1951) ; J. A. Nevis, 50 Cal. P.U.C. 609 (1951) ; Kings County Truck Lines, 50 Cal. P.U.C. 701 (1951); Stockton Motor Express, 51 Cal. P.U.C. 16 (1951). 
should be continued, the arguments lodged against it, and its long-term effect will be considered hereafter.

Turning to the commission's legislative proposals, active steps were taken during the 1949 session of the legislature to accomplish the passage of bills incorporating the proposed changes. ${ }^{84}$ However, concerted shipper opposition and internal disagreement among carrier interests served once again to defeat the remedial legislation which the commission believed so important. .5

The 1949 legislature did enact, at the instance of the petroleum haulers, special legislation which in the narrow field of petroleum tank truck operation, accomplished to a degree the kind of regulation which the Commission had advocated as appropriate for the transportation of all commodities. ${ }^{86}$ Radial highway common carrier petroleum tank truck operations were taken out of the Highway Carriers' Act altogether and placed in the Public Utilities Act, henceforth to be regulated in the same manner as highway common carriers, though given a special designation "petroleum irregular route carriers." Highway contract carrier petroleum tank truck operations were left in the Highway Carriers' Act but were given a special designation "petroleum contract carriers," and issuance of permits to them was made conditional upon establishing "ability and reasonable financial responsibility to intiate the proposed operations." 87 A curious indirect enjoinder was set forth at the end of the new provisions. Petroleum tank truck hauling was declared a highly specialized type of transportation and there was a caveat that the provisions respecting it were "not to be construed for any purpose as a precedent for the extension of such regulation to any other type of truck transportation." 88 It can hardly be doubted that the words must have been recognized to be no more than hortatory in their effect upon succeeding legislatures.

As a concomitant of the policy of liberality in granting certificates, the commission instituted a vigorous enforcement program designed henceforth to curb permitted carriers, radial or contract or both, from encroaching upon the highway common carrier field without certificates. At the threshold, however, the commission was met with two serious practical problems.

First, as to contract carriers, while the decisions of the California Supreme Court had consistently declared the dividing line between common and contract (private) carriage to be governed by a determination whether there was a holding out or dedication to serve the public or a portion

${ }^{84}$ Senate B. No. 1619, Assembly B. No. 3120, Calif. Legislature, 1949 Reg. Sess.

85 The Commission was successful only in that the Legislature took action to bring the City Carriers' Act in close conformity with the Highway Carriers' Act and also enacted provisions requiring the establishment of "ability and financial responsibility" as a condition to receiving a city permit. Cal. Stats. 1949, c.1419.

80 Cal. Stats. 1949, cc.1398, 1399.

$8 \pi$ Cal. Stats. 1949 , c.1398, $\$ 4$.

88 Cal. Stats. 1949, c.1398, § 4; Cal. Stats. 1949, c.1399, § 2. 
thereof, ${ }^{89}$ the decisions afforded no practical guide to the method of ascertaining the presence or absence of dedication. The decisions were wont to declare the question as one primarily of fact, ${ }^{00}$ then recite the evidence, then state the conclusion whether or not the evidence was sufficient to justify the determination below. The link between the recital and the conclusion was never supplied. Carriers had long complained, and rightly so, that the mere statement that there must be a dedication hardly explained the means for its determination.

Secondly, as to radial carriers the commission was faced with the phrase "between fixed termim or over a regular route" which while defined in Section $23 / 4$ (b) of the Public Utilities Act, had long given trouble in practical application and had in addition received the anomalous, emasculating interpretation of the Ben Moore ${ }^{91}$ decision discussed earlier.

To deal with the first of these problems and set forth practical guides by which dedication or the absence thereof could be determined in practice, the commission in Pacific Southwest Railroad Ass'n. v. Nielsen ${ }^{22}$ undertook to supply the link found wanting in court decisions. The commission started with the premise that dedication, the "unequivocal intention to dedicate property to a public use," must be determined by the objective standard of ascribed intent, that is, the intent which a reasonable man could or would ascribe to the carrier from a review of all the surrounding facts, including the carrier's subjective intent. The commission believed that such objective approach was that contemplated at common law and under the California regulatory statutes which concededly adopted the common law. Such objective approach seemed responsive to the public utility concept that certain types of business are clothed with a public interest, and therefore, as in the law of contracts, the important thing is what obligation the shipping public can reasonably ascribe from all the facts, including the carrier's actual state of mind. To take the other approach and conclude, by analogy to criminal law, that the carrier's actual state of mind is controlling, would be, it seemed to the commission, effectively to defeat the public utility concept, for then a carrier could, by refusing any business not appealing to it, keep itself always in the category of a private carrier and thereby maintain a great advantage over an operator more conscious of its social obligations.

Having started with the premise of ascribed intent, the commission in the Nielsen case then proceeded to classify all the relevant facts, including the carrier's expressions of intent, into two categories, those pointing toward and those pointing away from the conclusion, objectively viewed, that there

89 Producers Transportation Co. v. Railroad Comm'n., 176 Cal. 499, 169 Pac. 59 (1917), aff'd, 251 U.S. 228 (1920); Associated Pipe Line Co. v. Railroad Comm'n., 176 Cal, 518, 169 Pac. 62 (1917) ; Haynes v. MacFarlane, 207 Cal. 529, 279 Pac. 436 (1929); People v. Duntley, 217 Cal. 150, 17 P.2d 715 (1932) ; People v. Lang Transportation Co., 217 Cal. 166, 17 P.2d 721 (1932); George v. Railroad Comm'n., 219 Cal. 451, 27 P.2d 375 (1933) ; Landis v. Railroad Comm'n., 220 Cal. 470, 31 P.2d 345 (1934); Webb v. Boyle, 125 Cal. App. 326, 13 P.2d 785 (1932).

90 E.g., Haynes v. MacFarlane, supra note 89, at 532, 279 Pac. at 436.

91 Supra note 29.

9249 Cal. P.U.C. 216 (1949). 
was a dedication. The facts in the first category were described as showing an absence of restrictiveness in the carrier's business, those in the second category as showing a presence of restrictiveness. It was then a matter of administrative judgment, within the bounds of what a reasonable man could conclude, to determine whether the unrestrictive factors outweighed the restrictive, or vice versa. The commission went on to say that unless the restrictiveness were "substantial and considerable," such as "to allow a close identification or relationship of the carrier with the shipper's business or operation," ${ }^{94}$ the commission would find that there existed the dedication essential to common carriage.

The commission's approach to the problem was essentially the same as that expressed by the Interstate Commerce Commission in two leading decisions dealing also with the common law distinction between common and contract carriage. ${ }^{95}$ The only difference was that the federal commission took an even narrower view of the limits of contract carriage, saying that dedication would be found unless the "specialization," as it described it in lieu of the California Commission's term "restrictiveness," were such as to make the carrier "virtually a part" of the shippers' orgamzations. ${ }^{96}$

The Nielsen case, decided November 22, 1949, was not made the subject of court review and remained the guide by which the commission was governed until early in 1951, when the California Supreme Court rendered its opinion in Samuelson v. Public Utilities Commission. ${ }^{27}$ In that case the commission had avowedly applied the Nielsen test to a fairly small family operation which was restricted to about 30 shippers, new customers being substituted when old ones dropped out, and written contracts in stereotyped form being entered into whenever the shippers were willing, otherwise oral contracts being entered into. The commission marshalled all the facts which pointed toward restrictiveness in the operations and those which did not, and concluded that the carrier's business was not restrictive enough to show a close identification or relationship of the carrier with the shippers' business or operations. Therefore, under the Nielsen test, the operation was found to be common carriage.

Upon review, the suprene court, in a cryptic opmion, once again refused to go beyond a mere statement of the conclusion, conceded by the carrier and the commission alike, that "the common law test of common carriage, as repeatedly stated by this court, requires an unequivocal intention to dedicate property to a public use." 98 It declined to state whether unequivocal intention refers to the actual state of mind of the carrier or to that which reasonably may be ascribed to him, though it hinted at the former. It rejected the commission's test of "substantial restrictiveness," saying that

03 Id. at 224 .

$04 I d$. at 225 .

95 Craig, 31 M.C.C. 705 (1941); Midwest Transfer Co., 49 M.C.C. 383 (1949), aff'd, 51 M.C.C. 355 (1950).

90 Id. at 404 .

9736 Cal. 2d 722, 227 P.2d 256 (1951).

98 Id. at 733, 227 P.2d at 262 . 
that test "largely eliminates the factor of a dedication." construing the commission's test, whereby all factors, including the carrier's state of mind, are divided according as they point toward or away from restrictiveness in the operation and then are weighed in determining the ascribed intent, the court inexplicably remarked that "although the question of the carrier's intention is a primary factor in determining the character of carriage under the common law rule, the commission refuses to consider intent as tending to prove that status except where it happens to coincide with the determmation that there was 'substantial restrictiveness' in operations." 100

For reasons not revealed, the court took occasion to recite the holdings of the United States Supreme Court in Frost v. Railroad Commission ${ }^{101}$ and Stephenson v. Binford. ${ }^{102}$ Those decisions were irrelevant to the question whether Samuelson's operation was or was not common carriage, because they dealt with situations where the status of the carrier was conceded. Just as at the time of the Frost decisions the question of degree of control which the state may properly impose upon different classes of carriers had been confused with the question of status, so here the court apparently was guilty of like confusion but in reverse direction, since degree of control was not in issue.

In another decision following closely on the heels of the Samuelson case, Souza v. Public Utilities Commission, ${ }^{103}$ the court reiterated its views.

The unsatisfactory nature of the court's decisions in the Samuelson and Souza cases, both of which it had been generally hoped would provide the medium for authoritative guidance for determining dedication, had immediate repercussions. The law, if anything, was left in a less satisfactory state than before. The most that could be said was that contract carriage was a broader field than the commission had supposed, how broad no one could safely say. The field of contract carriage apparently afforded an avenue of limited regulation for those desiring to build up sizeable operations but wishing to avoid obligations to the public except to the narrow extent provided in the Highway Carriers' Act. For obvious reasons the commission's enforcement program in common-contract status cases had henceforth largely to be confined to the rare instances where a carrier without benefit of certificate accepted all business offered, or at least all business his equipment could conveniently handle.

Turning to the other problem of construction with which the commission was faced in seeking more effective regulation in the absence of reniedial legislation, that of delineating between highway common and radial highway common carriage, the commission chose Pacific Southwest Railroad Association $v$. Stapel, ${ }^{104}$ which was a conplaint proceeding involving

9936 Cal. $2 d$ 722, 732, 227 P.2d 256, 262 (1951).

$100 I d$. at 733,227 P.2d at 262 .

101. Supra note 24.

102 Supra note 47.

10337 Cal. 2d 539, 233 P.2d 537 (1951).

10449 Cal. P.U.C. 407 (1950). 
the status of a carrier, as the medium for expressing its views. Noting that the statutory distinction between the two types of carriage is solely that a highway common carrier is one operating a truck "used $\mathrm{m}$ the business of transportation of property as a common carrier . . . between fixed termini or over a regular route, $" 105$ and that a radial highway common is a common carrier not so operating, and that the words "between fixed termini or over a regular route" are defined to "mean the termini or route between or over which any highway common carrier usually or ordinarily operates any auto truck ... even though there may be departures from said termini or route, whether such departures be periodic or irregular," 106 the commission proceeded to develop what has since been described as the "integration theory." It was observed that where carriers claiming to operate under a radial permit serve between many pairs of termini in a particular area, the frequency of service is usually in direct relation to the population, industry, and business activity of the communities involved, that in consequence some pairs of termini are more frequently served than others. The commission concluded that where such a carrier, admittedly common because purportedly operating under a radial highway common carrier permit, conducts its business as a single, integrated business unit, using the same equipment, personnel, and terminal facilities, and issuing shipping documents in the same form and manner for transportation to all points served, and there is at least daily service between some of the pairs of termini involved or over any definable route, conducted on such a scale or in such a manner as to exhibit a permanent or indefinitely continuing nature, the entire operation should be held, in the absence of countervailing evidence of a different intent, to be "between fixed termini or over a regular route" even though some termini are in fact served, or some routes are in fact traversed, infrequently. ${ }^{10 \mathrm{~T}}$ The underlying reason for such conclusion was that under the circumstances outlined, a reasonable inference can be drawn, in the absence of contrary evidence, that the carrier in fact holds itself out to serve all points in the service area as frequently as called upon, so making all such points "fixed" and the routes between them "regular." The intent, viewed by objective standards, was thus substituted for the actual operation between any particular pair of termini or over any particular route as the criterion for determining whether termini are "fixed" or routes are "regular."

Admittedly the substitution of intent for operation in fact, brought with it a most awkward concept, that the holding out of radial highway common carriage is different from that of highway common carriage, the holding out of radial highway common carriage being to serve the public or a portion thereof only up to the point where there may be enough frequency between any one or more pairs of termini or over any particular route to render service between those termini "fixed" or that route "regular." Beyond the point described the carrier must refuse to serve or seek a certificate.

105 Cas. Pub. Ut. Code $\S 213$.

100 Cal. Pub. UT. Code $\$ 215$.

107 Pacific Southwest Railroad Association v. Stapel, supra note 104 at 413. 
The effect of the Stapel decision was to go considerably beyond earlier complaint or investigatory proceedings involving status, for the commission had always before refrained from going beyond a determination of unlawfulness except as to specific termini in fact served frequently, or specific routes in fact served frequently, without benefit of certificate. Such approach was predicated upon the construction that the statutes do not make a distinction between the holding out of highway common carriage and radial highway common carriage; the holding out is identical ni each case, but where in fact there is operation of sufficient frequency to render the ternini "fixed" or the routes "regular," a certificate must be obtained for those termini or routes. Support for such construction can be found in the language defining the words "between fixed termini or over a regular route" which seem to speak in terms of actual operation rather than intent. To quote again, they "mean the termini or route between or over which any highway common carrier usually or ordinarily operates. . . ."

The Stapel case which developed the commission's "integration theory" was not subjected to court review. The theory was subsequently applied, however, by the comnission in the Souza case. ${ }^{108}$ Upon review ${ }^{109}$ the court did not need to determine the validity of the theory because of its holding that there was no common carriage at all and, therefore, no occasion to distinguish between highway common and radial highway conmion carriage. However, in a cryptic obiter, the court seemed to reject the integration theory by the comment: ${ }^{110}$

The rule laid down by the commission in the Stapel case is that it will not consider a carrier's operations in segments, with each pair of termini representing a distinct segment of its business. By its reliance upon the Stapel decision in the present proceeding, the commission indirectly concedes that some of Souza's operations do not come within the definition of common carriage.

One can only guess at the meaning of this language. Certainly the commission would be the first to deny that it had made the concession with which it was charged.

Following the Souza case the commission felt constrained to withdraw from further application of the integration theory, and in recent decisions it has not found highway common carriage to be present except as to pairs of termini where actual physical frequency of service has been proved.111

The foregoing concludes the description of remedial steps which the commission has taken in the post-war years. The rate enforcenient program was alluded to ouly briefly because it has not entailed any problems of par-

10849 Cal. P.U.C. 745 (1950).

109 Supra note 103.

$110 \mathrm{Id}$. at 543 .

111 Illustrative is Nolan, 51 Cal. P.U.C. 685 (1952), in which the California Supreme Court granted review, see Sup. Ct., S. F. No. 18139, argued September 2, 1952. Also Flectlines, Inc., 52 Cal. P.U.C. 298 (1952). 
ticular difficulty aside from the interpretation of specific tariff provisions. ${ }^{112}$

Before concluding, mention should be made of a number of recent developments. ${ }^{113}$

In 1951 the legislature passed a special act for the regulation of household goods carriers, designated the Household Goods Carriers Act. ${ }^{114}$ Household goods carriers are defined as those engaged in the transportation for hire as a busmess "by means of a motor vehicle or motor vehicles being used exclusively in the transportation of used household goods and personal effects, office, store, and institution furniture and fixtures over any public highway." 115 Operations wholly within a city are excluded; however. All others, whether highway common, radial highway common, or contract, are taken out of existing statutes and made subject exclusively to the new act. A permit must be obtained as a condition to operation. Except as provided in certain grandfather provisions, the commission is required to issue a permit if the applicant establishes "ability and reasonable financial responsibility to mitiate the proposed operations." In most other respects the act follows the Highway Carriers' Act closely, providing the same mimmummaximum rate control, the same penalty provisions, and so on. The act has met with general approval, has entailed little difficulty, ${ }^{116}$ and has the great merit of making all carriers engaged generally in the same business subject to the same regulatory control, thus rendermg only academic the difficult distinctions between highway common, radial highway common and contract carriage. However, as in the 1949 petroleum carrier enactments, the legislature warned its successors not to construe the act as a precedent for other types of truck transportation legislation. ${ }^{117}$

In addition to enacting the Household Goods Carriers Act the legislature in 1951 created, pursuant to Senate Resolution, ${ }^{118}$ a Senate Interim Committee on Regulation of Highway Carriers for the purpose of studying the general problem of the regulation of highway carriers and reporting at the 1953 session of the legislature. ${ }^{119}$ That committee has conducted numerous hearings and has received the views of many interested parties including the commission.

113 A recent case is that of Alves, 51 Cal. P.U.C. 506 (1952), in which the carrier was ordered to cease tariff violations and collect undercharges. The Commission also brought a successful penalty suit in the Superior Court against the carrier. People v. Alves, Super. Ct., Alameda County, Civil No. 234919 (1952).

113 Until 1949 it was difficult for all but specialisist to keep abreast of significant current developments in the truck regulatory field. Since 1949 a careful annual analysis of recent developments in public utilities law written by Francis J. Carr, Esq., has appeared in the University of Santa Clara's Survey of California Law. See 1 Surver CALIF. I. 74 (1949) ; 2 SuRvey Calm. I. 83 (1950); 3 Survey Calif. L. 104 (1951); 4 Survey CaIm. L. 89 (1952).

114 Cal. Stats. 1951, c.974; amended by Cal Stats. 1951 , c.1726.

115 Cal. PUb. Ut. Code $\$ 5109$.

110 The Commission issued a decision, declaratory in nature, shortly after the enactment of the Household Goods Carriers Act, giving its administrative imterpretation of various provisions. Household Goods Carriers Act Interpretation, 51 Cal. P.U.C. 333 (1951).

117 Cal. Stats. 1951, c.974, § 24.

118 Senate Res. No. 213, Calif. Legislature, 1951 Reg. Sess.

119 Senator James E. Cunningham was made chairman of the committee. 
While it is too early to have knowledge of all the legislative proposals in the trucking field which may be offered during the regular 1953 session of the legislature, reference may be made to two bills already introduced. In the first, ${ }^{120}$ amendments are proposed which seek once again to eliminate the category of the radial highway common carrier and to place all motor common carriers under identical regulation. There are grandfather provisions to enable existing radial carriers to obtain certificates upon a showing of the operations which they have in fact conducted. The bill does not undertake to alter the existing limited requirements for obtaining a highway contract carrier permit, but it does provide for the filing of evidence that the carrier has written bilateral contracts with its shippers. The bill generally conforms with the suggestions made by the commission to the Senate Interim Committee. The second bill, ${ }^{121}$ sponsored by dump-truck interests, undertakes to place all dump-truck operations in a separate act, with regulation substantially like that now provided for household goods carriers.

Finally, reference should be made to the recent proceedings which resulted in disposition of a question which had arisen repeatedly since the enactment of the Highway Carriers' Act, subjecting radial highway common carriers to the maximum-minimum rate provisions of that Act. A group of certificated carriers in 1952 sought a writ of mandate from the California Supreme Court to compel the commission to require radial carriers to file rates with the commission, upon the theory that Article XII, Section 22, required such action for all common carriers, notwithstanding the provisions of the Highway Carriers' Act. ${ }^{122}$ The writ was denied. ${ }^{123}$ A second petition inet with like result. ${ }^{24}$

\section{Conclusion}

The most serious defect in the existing Califorma law respecting the regulation of truckers for hire lies in providing divergent treatment for two segments of the common carrier field, especially in the matter of regulation over entry into the business. Not only has the history revealed great technical and practical difficulties in delineating between the fixed-termini-regular-route common carrier and the non-fixed-termini-non-regular-route common carrier, but there appears to be little justification in this day for treating them differently. If the original purpose, at the time of passage of the Auto Stage and Truck Transportation Act in 1917, was to afford the railroads some measure of protection against the inroads of that part of the growing trucking industry which threatened the greatest competition, such

\footnotetext{
120 Senate B. No. 103, Calif. Legislature, 1953 Reg. Sess. Introduced by Senator Cunningham.

121 Senate B. No. 378, Calif. Legislature, 1953 Reg. Sess. Introduced by Senator Cunningham.

122 California Motor Transport Co. v. California Public Utilities Comm'n., Sup. Ct., S. F. No. 18594.

123 April 28, 1952.

124 California Motor Transport Co. v. California Public Utilities Comm'n., Sup. Ct., S. F. No. 18650, writ denied, October 27, 1952, rehearing denied, November 25, 1952.
} 
purpose has long since become submerged in the reality that little material difference can be detected between the competition which one segment of common carriage provides as against another.

In the matter of rates, it is true that with the advent in 1935 of maximuni-minimum rate control over the non-fixed-termini-non-regular-route carrier, the difference in treatment was substantially lessened. But in the matter of regulation over entry into the business, the gap is about as wide as it was in 1917. The permit requirement created in 1935 for entry into the non-fixed-termini-non-regular-route common carrier field gave virtually no control over such entry since permits had to be issued as a matter of course. There seems to be no sound reason why a certificate of public convenience should be required in one instance and not in the other.

Under existing conditions, with the door wide open for entry into one part of common carriage, the whole concept of certification for the other part is largely undetermined. This has actually been given recognition by the commission in its declaration that public convenience and necessity require that the bulk of the tonnage be carried by certificated carriers, and its consequent policy of liberality in the issuance of certificates. It would appear that such policy must go on indefinitely if "public convenience and necessity" continues to be given the content referred to, and if the door to entry in the radial field remains wide open.

The question arises whether certification should be required at all for trucking common carriage. A strong argument may be made that such business is affected with a public interest only to the extent of requiring regulation over service, safety and rates but not over entry into the field, and that the whole concept of certification should be abandoned. It may be argued that, unlike the case of electric, gas, telephone, water and other utilities where assets are relatively fixed and great economic loss might accrue from too much or, indeed, any duplication, the business of trucking admits of competition even to the point of letting the law of survival of the fittest govern, because the chief physical assets consist of individual trucks which are readily transferrable. It may be that under such a system ultimate rates to consumers would not need to be any higher than under a system of strict regulation over entry into the field. That is indeed the underlying basis for the legislation covering city carriers and the recent legislation covering household goods carriers.

Whatever the conclusion on this subject, the important thing is equality of treatment. Until the laws in California are made to provide like regulation over all common carriers carrying the same kind of commodities, regulation will leave something to be desired.

In addition to the foregoing problem, there is great need for an authoritative analysis of the distinction between common and contract carriage. Even here it may be argued that public interest does not require a difference in degree of control, and that has, indeed, been the legislative approach in dealing with city carriers and household goods carriers. Assuming, however, that some difference in control is desirable, it becomes of great practi- 
cal importance to have guideposts by which the dividing line may readily be discerned. As stated earlier, it is not enough merely to declare the conclusion that common carriage requires an unequivocal intention to dedicate. It is to be hoped that the Supreme Court will one day come to grips with this problem and provide the authoritative analysis so sorely needed. 